\title{
Free trade and exploitation
}

\author{
Libre Comercio y Explotación
}

CRISTIAN DIMITRIU*

\begin{abstract}
According to a popular view, defended by Pogge and other, trade agreements between wealthy and poor countries, as currently structured, are coercive and unfair for developing countries. Against this view, I argue that such agreements should be understood as exploitative instead of coercive. The difference between these two notions is a substantial one, as in the case of coercive proposals one of the parties is made worse off, while in the case of exploitative proposals both parties improve their situation. I rely on familiar accounts of coercion and exploitation, defended by Wertheimer, to make this point.
\end{abstract}

Key words: Global Justice, Pogge, Free Trade, Fair Trade, Coercion, Exploitation

\begin{abstract}
Resumen: De acuerdo con un punto de vista popular, defendido por Pogge y otros, los acuerdos comerciales entre países ricos y pobres, tal como están estructurados en la actualidad, son coercitivos e injustos para los países en desarro1lo. En contra de este punto de vista, argumento que dichos acuerdos deberían ser entendidos como explotativos en lugar de coercitivos. La diferencia entre estas dos nociones es sustantiva, ya que en el caso de las propuestas coercitivas una de las dos partes empeora su situación, mientras que en el caso de las propuestas explotativas ambas partes mejoran su situación. Me baso en concepciones familiares de coerción y explotación, tal como fueron defendidas por Wertheimer, para mostrar este punto.

Palabras clave: Justicia Global, Pogge, Libre Comercio, Comercio Justo, Coerción, Explotación.
\end{abstract}

Some of the trade agreements that are being widely discussed these days ${ }^{1}$ involve a proposal from developed countries to developing countries. The proposal, in theory, is to open the markets of all the parties in the agreement, so that everybody could benefit from having more places to sell their domestically produced goods. In practice, however, the proposal is to completely open the developing countries' markets to foreign trade and investments, while offering very little in return (namely, access to very specific products that cover some of the local needs of the developed countries). In addition, the agreements demand that developing countries implement flexible labour and environmental laws, tax exemptions, intellectual prop-

Fecha de recepción: 26/01/2013. Fecha de aceptación final: 15/07/2013.

* CONICET - Argentina. Becario Posdoctoral. Correo electrónico: cdimitriu@ hotmail.com. Se especializa en Justicia Global, Filosofía Política y Ética Normativa.

1 For example, the FTAA (Free Trade Area of the Americas) - an expanded version of the NAFTA that comprises all the countries of North America, Central America and South America. 
erty rights and other benefits, in order to create a friendly environment to foreign investors. The developing countries gain very little from the agreement, but they gain absolutely nothing if the treaty is not implemented. What drives developing countries to sign such asymmetric agreements is usually the vulnerable situation in which they are. In many cases the subsistence of their economy depends entirely on the exports of the only product they can offer for sale, and usually they face an urgent need to obtain hard foreign currency in order to pay their external debts or to maintain the stability of their otherwise volatile economy. The offerers, who tailor the terms of the treaty in their favor, exploit this vulnerability.

According to some global justice scholars such as Pogge, economists and general audience, such trade proposals are coercive and therefore harmful for developing countries. I argue, however, that it is a mistake to consider them «coercive», strictly speaking. Instead, the unfairness involved in these kinds of transactions lies in the fact that they are exploitative. The difference between coercing and exploiting someone is not just a semantic one. In fact, they are substantially different things, and they involve different kinds of wrongs. In this paper, I will proceed as follows. First, I will explain what a coercive proposal is, and will subsequently explain why Pogge is wrong in claiming that trade proposals are coercive. I rely on Wertheimer's account of coercion to make this point. Second, I explain what an exploitative transaction is (and, in particular, a mutually beneficial exploitative transaction) and claim that current international trade agreements should be understood as cases of mutually beneficial exploitation. I rely on Wertheimer's account of exploitation to make this point.

\section{Trade as a coercive proposal}

According to Pogge, trade proposals as the one described above (i.e. asymmetrical trade proposals made by developed countries) are coercive. The fact that he holds this view becomes evident when we look at the following quotes. In his own words,

We are harming the global poor if and insofar as we collaborate in imposing in $^{2}$ unjust global institutional order upon them. And this institutional order is definitely unjust if and insofar as it foreseeably perpetuates large-scale human rights deficits that would be reasonably avoidable through feasible institutional modifications ${ }^{3}$.

How exactly is the global order coercive? Pogge's main example is the one I discuss in this article: trade. In his view, international trade, as currently structured, is unjust and coercive to the poor because of asymmetric trading rules. As he puts it,

the current WTO treaty systems [...] permit the affluent countries to protect their markets against cheap imports (agricultural products, textiles and apparel, steel, and much else) through tariffs, anti-dumping duties, quotas, export credits and huge subsidies to domestic producers. Such protectionist measures reduce the export oppor-

2 The reader should notice the use of the term «imposes» in this quote. The fact that Pogge uses this term and not others such as «offers» or «proposes» suggests that he thinks of the global order as being forced upon the poor, and not as just voluntarily accepted by them.

3 Thomas Pogge, 'World Poverty and Human Rights', Ethics and International Affairs. 19.1 (2005), p. 5. 
tunities from poor countries by constraining their exports into the affluent countries [...] In the absence of these constraints, poor countries would realize welfare gains in excess of $\$ 100$ billion annually and reduction of several hundred millions in the number of the poor. The magnitude of this amount suggests that the WTO Treaty's high tolerance for rich country protectionism greatly aggravates severe poverty in the less developed countries ${ }^{4}$.

Now are these proposals really coercive? Following Wertheimer's account ${ }^{5}$, proposals are coercive when they are threats and not offers. A threatens B by proposing to make B worse off relative to some baseline; while A makes an offer to B by proposing to make B better off relative to some baseline. In more specific terms, there is a threat involved when, if B does not accept A's proposal, B will be worse off than the relevant baseline position; and there is an offer involved when, if B does not accept the proposal, he will be no worse off than in the relevant baseline. If a man proposes money to a beggar in return for a task (say, wash his car), there is an offer involved, because the beggar would not be worse off if he refuses the proposal. However, if the same man proposes to kill the beggar if he does not wash his car, then there is a threat involved because the beggar would be worse off if he refuses the offer. These are clear cases. The baseline against which we evaluate whether the beggar is worse or better off is simply the normal course of events without the man's intervention. In fact, had this person not made any proposal, the beggar would continue his sad beggar - existence unaltered.

Now, the relevant baseline could also be a moral one. While an agent that receives the proposal could be better off relative to a non-moralized baseline, he could still be worse-off relative to a moral baseline. Let us consider the following (well-known) example, provided by Nozick 6 .

\section{The drowning case}

$\mathrm{A}$ is drowning, and $\mathrm{B}$ offers $\mathrm{A}$ an agreement according to which $\mathrm{B}$ will throw $\mathrm{A}$ a life preserver only if A serves B for four hours a day for the rest of his life. It seems that it is rational for the person who is drowning to accept the proposal. It is clear, however, that the proposal is not a just one, if we admit that there was a previous moral duty from A to save B's life. With respect to that moral baseline (the duty to save B's life), A is coercing B

4 Thomas Pogge, Politics as Usual: What Lies Behind the Pro-Poor Rhetoric (Cambridge: Polity, 2010), p. 20. The italics are mine. Other readers of Pogge have also interpreted him as claiming that the international order, and in particular trade, is coercive. Leif Wenar, for example, holds that «Pogge's main moves are to expand our awareness of the coercive nature of the global institutions such as the World Trade Organization, to highlight the pervasive effects of these institutions on individual well-being, and then to extend the definition of human rights to comprehend entitlements against all those who support coercive institutions, whether these institutions are domestic or international.» See Leif Wenar, «The Nature of Human Rights», in Real World Justice, ed. A. Føllesdal and T. Pogge (Kluwer, 2005).

5 Wertheimer, Alan (1987). Coercion. (Princeton:Princeton University Press)

6 Nozick, Robert (1974). «Coercion.» In Philosophy, Science, and Method: Essays in Honor of Ernest Nagel. Edited by Sidney Morgenbesser, Patrick Suppes, and Morton White. (New York: St. Martin’s Press): pp. 440-472 
Let us assume that B prefers not to drown. Relative to a non-moral baseline, A is making an offer. In fact, he is proposing the drowning person to improve his situation. However, relative to a moral baseline, $\mathrm{B}$ is making a threat. There is a moral requirement according to which A should save B's life and, with respect to that moral baseline, the drowning person is worse off.

The upshot of this - and if we accept Wertheimer's account of coercion - is that if Pogge wants to show that trade agreements are coercive, he needs to be able to show that developing countries are made worse off relative to some relevant baseline.

One strategy to achieve this would be to show that countries are made worse off relative to the pre-transaction baseline if they accept asymmetric trade agreements. But this strategy would not be very promising: as explained (and stipulated) earlier, trade agreements are beneficial for developing countries after they are implemented. It is reasonable to expect this, as they have accepted them precisely because they obtain something out $f$ them. The problem with these agreements, let us recall, was not that they made one of the parties worse off, but rather that the benefit that one of them obtained was too small in comparison with the benefits that the other party obtained ${ }^{7}$.

A different strategy would be to claim that it could be rational and convenient for a developing country to accept an asymmetric trade proposal (in the sense that the overall situation of the country could improve); but that the agreement could still be an unjust one, because there is a previous basic human right to subsistence and, against that normative baseline, countries are made worse-off after the agreement is made ${ }^{8}$. But this statement would confront him with an obvious objection. In many cases, the weaker party is at fault for its inferior bargaining position. Perhaps the drowning person was about to die because he was drunk or irresponsible; and perhaps the developing country was in an inferior situation because its local government was corrupt, it implemented bad policies, or whatever. If that is the case, it is difficult to argue that developed countries had a previous duty to bring developing countries above the human rights threshold. In fact, they would be not responsible at all for the difficult situation in which poor countries are.

An analogy could illustrate this point. Suppose that we run into a beggar as we walk by and offer him a dollar to shine our shoes, just because he has a prior human right to a better life. In this case, the claim that we are coercing the beggar seems odd and counterintuitive. We are under no moral obligation to fulfill the right of the beggar to a better life just because we run into him. Moreover, if the person who offers the alms is not directly implicated in the causes that contributed to the poverty-situation of the beggar (which happens in most of the cases), the claim that he is coercing the beggar is even weaker.

Similarly, it could also sound odd to claim that developed countries are coercing developing countries when they are proposing an agreement that would benefit developing countries, just because people have a previous human right to a better life. Moreover, it

7 It is of course possible to reply here that some countries voluntarily accept trade agreements that make them worse off. One can imagine that they do this because their governments are corrupt, inept, or simply misguided. My argument, however, does not apply to these cases, so I will set them aside in the analysis. I simply assume that some (perhaps many) trade agreements involve disproportionate net benefits for both parties. The articles applies to these cases only.

8 I do not quote this argument because he suggested it to me in a private communication. 
is counterintuitive to claim that the developed country is coercing the developing one if it is not directly implicated in having created the circumstances that led to their failure.

The case of the drowning person mentioned earlier is a good example of a coercive proposal, because it is already clear what the duty to B is-i.e. to save his life-Relative to that moral baseline, B is rendered worse-off and his options are being unfairly reduced by A. But it is not clear that developed countries are obliged to raise the standard of living of citizens of developing countries above the human rights baseline. In other words, the relationship between countries is not obviously analogous to the relationship between the drowning person and the rescuer. One could argue that this analogy exists, but such a position certainly requires supporting some premises that not everybody would be willing to endorse. Moreover, even if this obligation existed, it does not seem possible to invoke it as a relevant baseline to assess the fairness/unfairness of trade agreements. If the human rights baseline were a relevant baseline in these kinds of situations, or in the case of the man who offers $\$ 1$ to a beggar in return for a task, then all proposals in which one of the parties remain below the human rights baseline after the proposal takes place would be unfair. To buy coffee from a coffee picker at an even «fair trade» price would be coercive on this account, because the recipient of the proposal would (presumably) remain below the human rights baseline after the transaction takes place. To offer an effective vaccine against some disease for a low price would also be coercive if one of the parties involved were below the poverty line before and after the proposal is accepted. But this seems implausible.

It seems, then, that Pogge cannot make the case of coercion, or that it would be difficult for him to make it, because the baseline that he proposes (i.e. the human rights baseline) is too demanding or inadequate.

\section{Trade agreements as cases of exploitation}

I would like to suggest, then, that we should understand trade agreements among developed and developing countries as cases of mutually advantageous exploitation, rather than as cases of coercion. According to Wertheimer ${ }^{9}$, mutually advantageous exploitation are agreements that satisfy the following two conditions: (i) both the exploitee and the exploiter gain from a transaction; and (ii) the benefit that one of the two parties obtains is unfair. In other words, mutually advantageous exploitation occurs when A and B gain in comparison to the non-transaction baseline, but where the distribution of benefits is unfair to $\mathrm{B}$. The benefit of not cooperating might be 0 (zero) for both A and B, and the net benefit of cooperating can be, say, 4 for $\mathrm{A}$ and 2 for B. Although both parties gain from the agreement, the agreement is exploitative if A's benefit is unfair. Wertheimer's gives the following example to illustrate this idea.

\section{The blizzard case}

An unexpected blizzard hits an area and people rush to the hardware store to buy a shovel. The hardware store owner sees the opportunity to make an abnormal profit and raises the price of a shovel from $\$ 15$ to $\$ 30$.

9 A. Wertheimer, Exploitation, Princeton: Princeton University Press, 1996. 
If $B$ agrees to pay $\$ 30$ for the shovel, because the shovel is worth more than $\$ 30$ to $B$ under the circumstances, then the transaction is advantageous to both parties. If $B$ is exploited, it is because $B$ has paid too much. The shovel case is not exploitative because one of the parties gains much more than the other one (if asymmetry of benefits were a sufficient condition of exploitation, then a doctor who over charges his patient for saving his life would be exploited. But this is implausible). The shovel case is rather an example of exploitation because A is charging an unfair price. This suggests that we should define what a fair price is, relative to which the transaction should be assessed. The fair price should stipulate how much parties ought to gain, if the agreement were fair. This baseline is not easy to specify. Wertheimer suggests that we should measure parties' gains against a hypothetical «fair market value». On this view, there is no objective and independent price for shovels. Rather, we compare the parties' gains by what they would have received under relatively perfect market conditions. In perfect market conditions, the seller and the buyer are well informed and unpressured. Also, neither party would take special unfair advantage of particular defects in the other party's situation. Consider the case of the drowning person. A exploits B if A were in the business of saving drowning people, but charged an unreasonable amount of money for his service. What makes this unreasonable request possible is the fact that $\mathrm{A}$ is in a position of monopoly. If others were competing for the same service at that time-in other words, if the market conditions in that context would have been perfect (or close to perfect)—A's offer would have been possible but completely implausible.

In order to argue that free trade agreements are exploitative, it is necessary, as in the shovel case, to find a standard of fairness against which we can determine that an agreement is unfair. What is, then, «free and fair trade»? Tempting at this point is simply to say that implicit in the notion of «free and fair» is the claim that both parties in the agreement will have equal access to each other's market. On this view, agreements seem unfair, then, not because people remain below the human rights baseline after trade agreements are signed, but rather because those who make the proposal are being inconsistent with their own moral standard in the first place - a moral standard which, by the way, both parties in the agreement share.

The problem with this line of thought is that not everybody would agree that free trade agreements ought to be equal and symmetrical. The predominant view among economists and many scholars, on the contrary, is that this moral requirement does not exist, and that talks of «fairness» in this context are misplaced. Any negotiation in which two rational parts participate and freely consent to an agreement is fair, they say, no matter what the outcome is. If country A offers country B an agreement that would result in the gain of 1 unit to country B and in the gain of 10 units to country A, and country B accepts this offer, there is no possible moral objection that could be raised to condemn B. After all, both parties freely consented to the agreement, and they did it in accordance to what they considered was their best interest. Had B not considered the outcome fair, he could made a different offer or drop the negotiation altogether. This view seems flawed. If fairness were misplaced in contexts like these ones, then basically any agreement, insofar as both parties rationally pursue it, would be fair. This seems false in cases of prostitution and low wage jobs, in which one of the parties voluntarily consents to the terms of the deal but is actually forced by the circumstances to accept them. 
What makes, then, the case of an asymmetric trade deal exploitative? How would the idea of a hypothetical fair price work in that case? The first thing to have in mind, I believe, is that it is not really central to this account to try to find a «fair» price for the goods that are being exchanged, for the asymmetry in the agreements do not lie in the fact that one of the parties demands an unreasonable amount of money for the product they offer, but rather in the fact that one of the parties obtains much better opportunities to invest and to sell their domestically produced markets than the other. So it seems that rather than trying to derive a hypothetical «fair price»; what we need to do is find the terms of the agreement that both parties would accept if they were not under duress, and if they could have access to all the relevant information ${ }^{10}$. Under such hypothetical conditions, I believe, parties would engage in a trade agreement only if they can both have equal access to each others' market. They would try, in other words, to maximize the benefit that they could obtain from the deal and, consequently, they would reject all the suboptimal scenarios. Also, if these hypothetical conditions existed, none of the parties would take advantage of the fact that the other party desperately needs investments by demanding extremely low environmental standards or flexible working conditions. If the options of two equal parties are to gain 0 by not agreeing anything, to gain 2 and let the other party gain 8, or to gain 5 units each, then it seems more plausible to assume that they will both agree on the latter scenario. Otherwise, and considering that none of the parties would want the 8-2 scenario, they will end up not obtaining any benefit at all. In a world in which one of the parties desperately needs an agreement, and the other party knows it, there would be room for the stronger party to speculate and reach an agreement in which there is an 8-2 benefit.

However, how to interpret these conditions is not an obvious task. Should benefits be distributed progressively among trade members (i.e. in a way that those who are worst-off benefit more than those who are better-off)? Should historical trade asymmetries be taken into account or only currently existing trade practices? Should the benefits be proportionate to the size the parties' economy, or should they be distributed equally among trading partners? These and other related questions do not have an obvious answer. In any case, it is not hard to imagine that two parties that are negotiating under similar conditions, free from extreme background conditions, would reach a very different agreement from the ones that they currently accept. A hypothetical fair agreement would not be, of course, a deep principle of justice in any interesting philosophical way, but it refers to an important moral aspect of the relationship between parties. The hypothetical fair agreement is an agreement in which neither party takes special unfair advantage of the others' vulnerabilities or defects. Probably some transaction would never occur under certain hypothetical conditions. I doubt that we could find a fair transaction baseline for prostitution or organ sales, as virtually nobody, I believe, would be willing to enter into those kinds of deals if they were not forced by the circumstances or fully informed of their consequences. But trade agreements do not seem to fit into this range of cases.

Trade agreements could be considered exploitative, then, on the basis that one of the parties (i.e. the one that mostly benefits from the agreement) benefit unfairly from the agreement. In order to determine that this benefit is «unfair», we should establish a moral standard

10 This condition refers not only to the governments but also to the citizens of each of the countries involved. 
against which we could assess the morality or immorality of current trade regimes, and its scheme of benefits. This standard of fairness, I believe, could be derived by following the same strategy that we followed in the shovel case. We think of the shovel case as exploitative because one of the parties takes advantage of its monopolistic position and of the fact that the buyer is under duress. The price he charges, we could say, is unfair, because in a hypothetical market arrangement in which there are perfect or near perfect market conditions, the price he charges would be different. Similarly, we could say that in trade agreements, as they are currently structured, one of the parties benefit unfairly, relative to a hypothetical market arrangement in which both parties are not under duress and are fully informed of the consequences of their action.

In finding a candidate moral baseline to assess free trade agreements, we should reject, I believe, the human rights benchmark. When we reject this benchmark, the case for coercion disappears. However, if we analyze these agreements in light of a different and relevant moral baseline, it seems plausible to understand them as a case of mutually advantageous exploitation.

\section{Conclusion}

In this paper, I have analyzed and criticized the popular assumption (put forward, among others, by Pogge) that trade agreements, as currently structured, are coercive. In light of recent developments of normative accounts of exploitation and coercion, proposed by Wertheimer, I argue that it is mistaken to treat such agreements as coercive. Rather, they should be understood as exploitative. The difference lies in the fact that coercion involves making an agent worse off relative to a moral or pre-transaction baseline; whereas exploitation involves making someone better off, but by offering an (unfairly) disproportionate distribution of benefits. Given that in these kinds of trade agreements none of the parties are made worse off relative to any moral baseline, but that the benefits are unfairly distributed relative to ideal market conditions, we should conclude that trade agreements are exploitative. 